\title{
Report on the Exchange Programme between Young Lawyers from Central and East Africa and the Judiciary of Baden-Württemberg and Rheinland-Pfalz, Germany, in Lubumbashi (Democratic Republic of Congo), Kigali (Rwanda) and Nairobi (Kenya) from 6 to 15 February 2016
}

Aniello Ambrosio, Mirjam Bäumer-Götz, Caroline Gräser, Mario Mannweiler, Carola Osswald, Cornelia Rank, Christian Trauthig*

In February 2016 seven German judges and public prosecutors of the judiciary of BadenWürttemberg and Rheinland-Pfalz had the great opportunity of a ten-day-visit to either Rwanda or the Democratic Republic of Congo (DRC) and a joint conference on "Requirements for an Independent and Effective Judiciary" in Nairobi, Kenya. The whole visit was part of an exchange programme between young lawyers from Central and East Africa and the judiciary of Baden-Württemberg and Rheinland-Pfalz. From 5 to 18 October 2014 seven African lawyers (prosecutors, advocates and a judge) from Burundi, Rwanda and the DRC had already come to Stuttgart, Germany. ${ }^{1}$ The exchange programme was organized and coordinated by Professor Hartmut Hamann of the African Law Association and the Robert Bosch Foundation in cooperation with the competent Ministries of State and Justice of Baden-Württemberg and Rheinland-Pfalz. ${ }^{2}$ During the first part of the visit, four members of the German delegation went to Lubumbashi, DRC, while the other three members travelled to Kigali, Rwanda. The second part of the visit brought the German participants, their African exchange partners and other young lawyers from Central and East Africa together in a conference in Nairobi, Kenya.

* Aniello Ambrosio, Dr. Caroline Gräser (Staatsanwaltschaft Stuttgart) and Mario Mannweiler (Generalstaatsanwaltschaft Koblenz) are public prosecutors. Mirjam Bäumer-Götz (Amtsgericht Stuttgart), Carola Osswald (Amtsgericht Waiblingen), Cornelia Rank and Christian Trauthig (both Landgericht Stuttgart) are judges. This report solely represents the personal opinion and impressions of the authors.

1 Kahombo, Balingene: Summary Report on the 'Exchange Programme between Young Lawyers from Burundi, Rwanda and the Democratic Republic of Congo and the Judiciary of Baden-Württemberg (Germany)' from 5 to 18 October 2014, in: Recht in Afrika - Law in Africa - Droit en Afrique 17 (2014), pp. 228-236.

2 For more information regarding the exchange programme see Sippel, Harald: Förderung der Justiz in Afrika: Austauschprogramm zwischen Baden-Württemberg und zentralafrikanischen Staaten, in Recht in Afrika - Law in Africa - Droit en Afrique 17 (2014), pp. 113-115, and Sippel, Harald: Förderung der Justiz in Afrika: Konferenz zur Unabhängigkeit und Effizienz der Justiz in Lubumbashi und Fortsetzung des juristischen Austauschprogramms zwischen Baden-Württemberg und zentralafrikanischen Staaten, in Recht in Afrika - Law in Africa - Droit en Afrique 18 (2015), pp. 139-142. 


\section{Impressions of the visit to Lubumbashi, DRC}

Arriving in Lubumbashi in the warm rainy season from a cold German winter was like plunging into a whole new world. The experience already began at the small but somehow confusing airport, where we were glad to be helped by our local exchange partners with customs formalities. The whole visit was sometimes adventurous but highlighted by a warm welcome, great hospitality, a full and diversified agenda and an excellent exchange of opinions and ideas with our hosts: a judge, a public prosecutor, two advocates and a professor of the University of Lubumbashi.

\section{Schedule of the visit}

The first day we had the opportunity to be received by several judicial authorities: the Presidents of the Higher Regional Court and the Regional Court as well as the head of the local Public Prosecutor's Office. Afterwards we were shown around the Palais de Justice and then visited the Public Prosecutor's Office at a Local Court in one of the suburbs of Lubumbashi. In the afternoon we accompanied our exchange partners to their offices where we were made familiar with their daily routine. The next day we attended a Civil Court hearing at the Regional Court. In the afternoon we had the opportunity to meet the Rector of the University of Lubumbashi. In addition we presented the German judicial system and the role of women in the judicial system in a lecture at the Law Faculty, followed by a lively discussion with the students. On the morning of the third day we met our exchange partners and we discussed several topics linked with the enhancement of an independent judiciary in the DRC. Later that day we attended a conference at the Bar Office on "Requirements for an independent and efficient judicial system in Germany and the DRC". Presentations were given by the head of the Public Prosecutor's Office, a local judge, the head of the Bar Office and members of the German delegation, followed by a discussion. The next day we left Lubumbashi for Nairobi.

\section{Impressions}

A few weeks after our stay in Africa we learned that more or less all of the judicial authorities we had met during our visit had been replaced by others. This leads us to, in our opinion, the greatest obstacles in implementing an independent and effective judiciary in the DRC: the influence of politics and powerful individuals or companies on the judicial body, insufficient funding and corruption.

(a) In theory the legal and judicial system is very similar to the Roman-German system as can be found in Belgium or France and should provide a functional frame for an independent and effective judiciary. But in practice this legal and judicial system faces immense challenges: a system of political influence and pressure imposed by phone calls, replacement of competent judges for various reasons and the attempt of influencing a certain judgement, promoting execution of a judgement or hampering it. The inexistence of the 
principle of a legally competent judge facilitates the exertion of influence on judges. Wrongful interference by politicians seems also to be on the daily agenda of prosecutors. While in countries like Germany the authority of the respective minister to give certain directives exists but is almost never used, in the DRC this right seems to be exercised quite often.

(b) Moreover, the working and personal conditions of the judges and prosecutors are generally yet to be improved. This is not only necessary regarding the salary but also the infrastructure, furniture and working material. Some offices are located in run-down buildings with holes in the ceiling. Prosecutors have to share rather small rooms with colleagues and provide their furniture, paper and computer themselves. We heard from judges that their independence is guaranteed by the Constitution, but only theoretically as the working conditions are insufficient regarding salary, qualified staff members, infrastructure and a lack of personal security of the judges even around their private homes.

On the other hand a visit of the modern and impressive stadium of the very popular soccer club TP Mazembe showed us that if there is a will to provide a modern and functional infrastructure there is always a way. Regarding the judiciary there seems to be a lack of will of doing so. In a suburb of Lubumbashi there is a new and modern Public Prosecutor's Office building which was sponsored by a local mining company. A sign in front of the building proudly tells of the sponsoring. The politically responsible persons do not seem to mind problems arising from this private sponsoring regarding an independent judiciary.

(c) All this also leads to a negative reputation of the judiciary. We were told that a survey showed that $80 \%$ of the population in the DRC have no faith in the judicial body and try to avoid court proceedings if possible, above all fearing corruption. They prefer private settlements between the families involved, sometimes with the help of their religious communities. Bringing a case before the courts is also expensive because all the fees normally have to be paid in advance. Even if a favourable judgement is obtained, significant fees for its execution need to be paid by the party itself. In the end, however, there are still mechanisms, mostly the influence of important people or even the executive power, to stop the execution of a judgement. The same applies to criminal prosecution. Although the authorities are legally obligated to enforce the law ex officio, as a matter of fact due to their low income state officials often only act if paid in advance by the victims of a crime.

It should not remain unmentioned that cases in the DRC can however, also be dealt with efficiently and in due time. For example, we learned about a case that was handled in an accelerated procedure. Amongst others, civil servants were prosecuted. For us, the exact reasons why a case goes one way or the other remained unresolved.

\section{Conclusions}

Altogether we had very interesting days in Lubumbashi full of rich experiences and impressions. From our point of view there is not much that needs to be changed in the Congolese legal system in theory. As already stated, it is very similar to the legal systems in Europe. 
The problems rather arise from the way the legal system is applied in practice. In our opinion there are three main factors that have to be considered: first of all the attitude of politicians and individuals of influence. As long as they continue to try to influence the judiciary, do not effectively combat corruption and do not provide a sufficient infrastructure within the judicial system, it will be difficult to change things for the better. Secondly an independent and efficient judiciary depends on the conduct of the judges, prosecutors and lawyers involved. During our stay, we met many prosecutors, judges and advocates that were more than willing to speak openly about problems that may arise within the Congolese legal system. We appreciated these lively discussions a lot. In our opinion, this is a first important step towards an independent and effective judiciary in the DRC and allows to hope for changes in the future. Last but not least it needs a lively civil society and media scene that strongly demands for an independent judiciary and reveals possible deficits. It needs patience and time to change things for the better, but it is well worth fighting for it.

Apart from these conclusions, drawn from a professional point of view, we will fondly remember our time in Lubumbashi and all the efforts taken by our Congolese partners in showing us their judiciary.

\section{Impressions of the visit to Kigali, Rwanda}

The visit of the German lawyers at the Rwandan Supreme Court started with an introduction of this court and of the Inspectorate of Courts Department. The institution of an Inspectorate of Courts Department was something unknown to us. The Court Inspectorate is a body within the judiciary which consists of five inspectors/senior judges of the High Court in charge of monitoring and ensuring policies adopted to deliver timely and fair justice. The Inspectorate of Courts Department is pursuing the following goals:

- Access to justice refers to the ability of people to seek and obtain a remedy through institutions of justice and in conformity with human rights standards.

- The right of access to justice can be enjoyed only if justice is transparent, delivered at a minimal expense and within reasonable time.

- Delivery of fair and timely justice.

The job description of the Court Inspectorate includes for example:

- Receive and process complaints from the public;

- Evaluate court performance;

- Identify weaknesses and propose areas of training;

- Conduct research and develop legal materials to provide judges with well searched legal information and updated jurisprudence;

- Devise ways of consistently improving case management and application of IT solutions in order to modernise justice delivery;

- Develop policies aimed at improving court administration; 
- Develop and instil standards of professionalism and ethics, and prepare reports on disciplinary issues of judges and court staff to the High Council of the Judiciary;

- Coordinate and supervise law reporting activities;

- Develop and implement communication strategies to better inform the public on how the judiciary operates and create confidence in the population towards judiciary.

The average time it takes for a litigant to have his case disposed at the Supreme Court is 2.5 years. In other courts the standard time of six months fixed by the law to process a case and deliver judgement is generally observed. Delaying tactics by the attorneys are sanctioned by payment of a fine.

Most cases are and must be handled by Mediation Committees (Abunzi). Arbitration courts at grass root level are in charge of solving minor civil (not exceeding five million Rwandan Francs - about 6,000 US-\$) and criminal litigations (where penalty does not involve imprisonment). It is mandatory to handle such cases at Abunzi before they can be admitted to Primary Courts. Only in case the party is dissatisfied with Abunzi decision the case can be transferred to ordinary courts. The system of Abunzi has proven to be citizenfriendly to the extent that $80 \%$ of cases handled by Abunzi do not even come to court.

Rwanda is on its way to an Electronic Filing System (EFC). So far, in the Supreme Court and in the Commercial courts, 100per cent of cases are electronically filed. In the High Court, it is 70 per cent and slightly lower in the Intermediate Courts and the Primary Courts. The EFC is based on email correspondence. Filing pleadings electronically has the advantage that there is no direct contact between applicant and decision-maker. This means one opportunity less to bribe someone. Disadvantageous from a German point of view is the failing of data security. An integrated electronic case management system which will allow all institutions involved in justice delivery to process cases and share information/ files faster is being tested. It also allows litigants to follow up the progress of their cases online, either through their respective lawyers, cyber café or even through their smartphones.

As the judges of the Supreme Court and some of the lecturers told us, Rwanda has kept on improving the law, bringing in innovations and incorporating best practices derived from the Rwandan culture and borrowed from different parts of the world. For example, the foundation is a civil law system in combination with elements of case law and leading decisions that are binding for the lower courts.

Another surprise for us was that the Chief Justice decides about the bench which handles the case and makes the monthly schedule. According to German Constitution the judges or the bench have to be determined before a case comes to court. So each court has an organization chart.

At the National Public Prosecution Authority (NPPA) the German participants of the exchange programme with the Judiciary of Rwanda got their first deep insight into Rwandan Criminal Law. The Prosecutor General himself and the Deputy Prosecutor General greeted the German Judges and Prosecutors. Both the German and the Rwandan Prosecutors introduced the other party to their own criminal jurisprudence. Under the roof of NPPA 
more than 100 prosecutors on the levels of Primary, Intermediate, High and Supreme Court investigate all kinds of crimes except minor infractions that are settled by the Mediation Committee. Although the public prosecutors are appointed by prime minister's order - i.e. by an executive order as it is the case in Germany with the State Ministries of Justice NPPA as a whole is an independent authority with an own budget allocated for one period. Like in Germany the Minister of Justice is allowed to give the prosecutors written instructions how to deal with a certain case for issues of public interest. What impressed the German participants the most was the fact that also in the NPPA there was established an Inspectorate Department. The Inspector General who must have been a prosecutor himself and therefore know the prosecuting exercise is responsible for the supervision and control of the functioning of the NPPA in terms of budget spending, investigating and law enforcement activities. The Inspectorate Department is working independent from any executive order. This measure of control of the functioning of the prosecuting authorities is not known to the German Legal System.

As the Rwandan Legal System is developing since the end of the armed conflicts in the Mid-1990s the state established a more professional training. Public prosecutors have to produce the minimum qualification of a bachelor's degree in law. Prosecutors working on lower levels of jurisdictions can be promoted temporarily by contract for a short period of six months. Also in Germany public prosecutors shift for up to nine months to the General Public Prosecutor's Office in order to demonstrate their abilities and later promotion. But the status of these prosecutors remains unchanged. What did not get quite clear to the German lawyers is the influence of the status of the single prosecutor on the investigating proceedings.

Since a couple of years NPPA built up an International Crime Investigating Unit. The German participants got to know some of the highly motivated prosecutors during their visit. The Rwandan Government worked hard on the regulations for Legal Assistance and extradition to assure the events of war crimes and genocide can be clarified properly. For this reason accused persons got e.g. the right to cross-examine witnesses. The latter do not have to fear prosecution in Rwanda when they are traveling from abroad as they are given immunity to testify the real happenings. NPPA opened up a Witness Protection Unit which deals with witnesses giving decisive testimonies. Courts and prosecution do monitor the activities of this department. In case it is not possible to get a witness into the country, it is possible in Rwanda - in contrast to the general German Criminal Proceedings - to read written witness testimonies in main proceedings. The NPPA is also able to give certain procedural guarantees to extraditing countries as any suspect person is given a defence lawyer upon request and death penalty has been abolished in 2006. NPPA is largely cooperating with foreign countries, especially from Europe and Northern America, and with the - now dissolved ICTR in Arusha, Tanzania. The German lawyers as well as the Rwandan Public Prosecutors concluded their visit with the statement that given these facts also Germany may in future extradite fugitives and suspects to Rwanda. 
Another very interesting institution the German judges and public prosecutors visited in Rwanda was the Office of the Ombudsman. An ombudsman is an official, appointed by the government, who is charged with representing the interests of the public by investigating and addressing complaints reported by individual citizens.

Although the term "Ombudsman" is of Swedish origin, the idea of an independent institution representing the interest of citizens has traditional roots in Rwanda going back to the time of monarchy. In Kinyarwanda, the Rwandan native language, "Ombudsman" is called "Umuvunyi". During kingdom period "Umuvunyi" was a person in charge of receiving citizens who wanted to meet the king for different reasons, such as bringing a complaint, thanking him or warning him on a given issue. It was mandatory to talk to the "Umuvunyi" before having an audience with the king and it was up to the "Umuvunyi" to know if that person has to meet the king or if he/she has to be referred to another relevant organ.

The Ombudsman's office in Rwanda is a relatively unique institution because it combines the responsibilities of a traditional ombudsman with those of an independent anti-corruption agency. The Office was created as an independent body in 2003. It is headed by a Chief Ombudsman who is nominated by the President and approved by the Senate of Rwanda. He or she is appointed to a four years term that can be renewed only once. By law the Chief Ombudsman can only be removed by the Parliament.

The Ombudsman's explicit mandate is to reinforce good governance in both public and private institutions by acting as a link between the public and these institutions, preventing injustice and corruption, receiving complaints from citizens, and administering the income and asset disclosure system of the government.

To understand the tasks and aims of the Ombudsman it is important to know that the Government of Rwanda has undertaken a number of anti-corruption measures with immense political will. Therefore combating against corruption is one of the most important tasks of the work of the Ombudsman.

The Ombudsman's office was structured in a manner to set the focus primarily on the prevention of corruption through education and training and in-depth auditing of government institutions for the purpose of identifying procedural weaknesses permitting corruption. It conducts operational audits in public and private institutions in order to identify loopholes of corruption that may exist. This strategy has been supplemented with a more direct anti-corruption capability housed in the newly formed Special Investigation on Corruption Unit within the Office of the Ombudsman which has been granted the power of preliminary investigation of all instances alleged with corruption with police-like powers.

Furthermore, the Office of the Ombudsman receives annually the declaration of assets from persons determined by law and verifies its accuracy and origin. This helps in identifying people with illegally obtained assets. It also receives annually the declaration of assets of political organizations and verifies their origin and their use. Those who do not declare their assets face sanctions.

Relatively new and - from an European point of view - very remarkable is the stipulation that the Office of the Ombudsman has powers to request the Supreme Court to recon- 
sider and review judgements rendered at the last instance by ordinary courts, commercial and military courts, if there is any persistence of injustice. The reconsideration and review shall be made in accordance with the Organic Law, establishing the organization, functioning and competence of the Supreme Court.

The learnt experience and lessons in Kigali showed that law is part of the society and must fit accurately to the current situation of the country. Improvement must look and start at the concrete situation of the society, country and law. A perfect law or jurisdiction is an imagination. Law and jurisdiction must always try to improve and fit to the current political and social situation. Therefore, it will always be helpful to exchange with other countries and learn from each other. In order to promote mutual understanding and legal discussion between European and African judges and public prosecutors it is recommendable to exchange on a grass root level in future. Unfortunately, this time it was not possible to share professional everyday life with the Rwandan counterpart.

\section{Conference in Nairobi, Kenya}

The conference on „Requirements for an Independent and Effective Judiciary“ was attended by the German participants of the exchange programme, their exchange partners from Rwanda and the DRC and other young lawyers from Burundi, Rwanda, the DRC, Kenya, Tanzania and Uganda. ${ }^{3}$ The conference gave the opportunity to exchange views on the independence of the judiciary in the East and Central African countries the participants came from. The discussion showed that all these countries face problems in installing a genuinely independent and effective judiciary. But the situation varies from country to country. Whereas Kenya on the one hand seems to be on a good way in Burundi on the other hand things deteriorate continually.

Altogether the conference was a good addition to the visits in Lubumbashi and Kigali and completed our experiences.

3 For more details see the conference report in this issue, authored by Magdalena Sylister and Balingene Kahombo. 